\title{
Artikel
}

\section{Franchise: is artikel 7:922 BW een voorrangsregel waar de praktijk op moet voorsorteren?}

Prof. mr. dr. Edwin van Wechem en mr. Michiel Bijloo*

\section{Inleiding}

De Tweede Kamer heeft het wetsvoorstel inzake de Wet franchise op 16 juni 2020 met algemene stemmen aangenomen. Op 30 juni 2020 volgde de Eerste Kamer, waarmee de wet is aangenomen. ${ }^{1}$ De wet treedt mogelijk al op 1 januari 2021 in werking. ${ }^{2}$ Er is aardig wat te doen geweest over het wetsvoorstel, en het heeft daardoor geleid tot een behoorlijk oeuvre aan juridische literatuur. ${ }^{3}$

Deze bijdrage ziet op een specifiek aspect van de nieuwe wet, en wel op artikel 7:922 Burgerlijk Wetboek (BW). De tekst van artikel 7:922 BW luidt als volgt: 'Ten aanzien van in Nederland gevestigde franchisenemers geldt dat van het bepaalde bij deze Titel niet ten nadele van hen kan worden afgeweken en dat een beding in strijd met artikel 920 nietig is, ongeacht het recht dat de franchiseovereenkomst beheerst.' In deze bijdrage onderzoeken wij of dit artikel 7:922 BW de betekenis

Prof. mr. dr. T.H.M. van Wechem is hoogleraar Corporate Legal Counseling aan de Open Universiteit en redacteur van Contracteren. Mr. M. Bijloo is advocaat en counsel bij BakerMcKenzie advocaten en notarissen te Amsterdam.

1. 30 juni 2020 (Kamerstukken II 2019/20, 35392, nr. 34, Stb. 2020, 251).

2. Handelingen II 2019/20, nr. 80, item 28, p. 12.

3. Zie bijv. H.N. Schelhaas \& J.H.M. Spanjaard, Het Wetsvoorstel franchise: verbeterd, maar nog steeds werk aan de winkel, Contracteren 2020/2, p. 47 e.v.; A.W. Dolphijn, Collectieve acties van franchisenemers, Contracteren 2020/1.
- en status - kan hebben van een zogenoemde voorrangsregel in het internationaal privaatrecht (ipr), meer precies: in de zin van artikel 9 Rome I Verordening. ${ }^{4}$ Praktisch en kort gezegd: zal de aangezochte rechter in een geschil bij een internationale franchiseovereenkomst een eventuele keuze door partijen van buitenlands recht opzijzetten en overschrijven door het bepaalde in artikel 7:922 BW?

\section{Achtergrond}

Lid 1 van het oorspronkelijk voorgestelde artikel 7:922 BW luidde als volgt: 'Van het bepaalde bij deze Titel kan niet ten nadele van de franchisenemer worden afgeweken.' Lid 2 bepaalde vervolgens: 'Een beding in strijd met artikel 920 is nietig. ${ }^{5}$ Het lijkt uit de memorie van toelichting te volgen dat artikel 7:922 BW doelde op 'gewoon' dwingend recht (dat wil zeggen bepalingen waarvan - bij toepasselijkheid van Nederlands recht niet door partijen bij overeenkomst kan worden afgeweken), en niet specifiek op een voorrangsregel ex artikel 9 Rome I Verordening. Deze opvatting vindt steun in de memorie van toelichting, die in dit verband vermeldt dat waar zowel franchisegever als franchisenemer een Nederlandse partij is, en de franchiseovereenkomst uitsluitend met Nederland is verbonden, een eventuele rechtskeuze voor niet-Nederlands recht de bepalingen 
van de franchisewet niet opzij kan zetten. ${ }^{6}$ Met andere woorden, waar beide partijen niet Nederlands zijn, of - waar dat wel het geval is - de franchiseovereenkomst niet exclusief met Nederland is verbonden, kunnen partijen wél afwijken van de franchisewet. Dit strookt ook met de structuur en opzet van artikel 3 Rome I Verordening, waarin de vrijheid van rechtskeuze door partijen bij een internationale overeenkomst centraal wordt gesteld.

Tot zover ogenschijnlijk geen onduidelijkheid. Maar vervolgens hebben de Kamerleden Palland en Aartsen met een amendement de tekst van artikel 7:922 BW gewijzigd in het definitieve voorstel zoals hiervoor in de inleiding uiteen is gezet. ${ }^{7}$ De toelichting op het amendement stelt dat met de wijziging wordt geregeld dat niet ten nadele van in Nederland opererende franchisenemers van de Wet franchise mag worden afgeweken. Dit wijst onzes inziens derhalve op een gericht protectionistische bescherming van een geselecteerde groep franchisenemers, zodat hierbij de vraag kan opkomen of daarmee het uitgangspunt van contractsvrijheid, voor zover die gericht betrekking heeft op het vrijelijk uitbrengen van een rechtskeuze, daarmee onder druk komt te staan. Afwijkingen ten aanzien van buiten Nederland opererende franchisenemers zijn namelijk wél toegestaan. ${ }^{8}$

Het doel van het amendement was tweeledig. Allereerst het bieden van bescherming aan in Nederland opererende franchisenemers in gevallen waarbij het overwicht van de franchisegever tot onredelijke en onwenselijke situaties kan leiden voor de franchisenemer. Daarnaast het bieden van maatwerk aan franchisegevers en franchisenemers in Nederland. ${ }^{9}$ Het amendement adresseert de internationaal privaatrechtelijke aspecten echter verder niet.

\section{Voorrangsregel artikel 9 Rome I Verordening? ${ }^{10}$}

Dit brengt de vraag op wat thans de status is van artikel 7:922 BW. Gaat het hier om een voorrangsregel of bepaling van bijzonder dwingend recht als bedoeld in artikel 9 lid 1 Rome I Verordening? ${ }^{11}$ Zo ja, zal de Nederlandse

6. Kamerstukken II 2019/20, 35392, nr. 3, p. 50, en dit wordt herhaald in de nota naar aanleiding van het verslag, Kamerstukken II 2019/20, 35392, nr. 6, p. 27

7. Kamerstukken II 2019/20, 35392, nr. 10. Voor de goede orde: het amendement is van 9 juni 2020. De nota naar aanleiding van het verslag (Kamerstukken II 2019/20, 35392, nr. 6) is gedateerd op 19 juni 2020. Echter, de opmerkingen in deze nota zien klaarblijkelijk op de oorspronkelijke tekst van art. 7:922 BW, niet op de uiteindelijke tekst.

8. Kamerstukken II 2019/20, 35392, nr. 10, p. 1.

9. Kamerstukken II 2019/20, 35392, nr. 10, p. 2

10. Zie over de reikwijdte van de voorrangsregels onder Rome । Verordening algemeen: T.H.M. van Wechem, Rome I: verscholen ingewikkeldheden, pre-adviezen voor de Nederlandse Vereniging voor Internationaal Recht, TMC Asser Press 2008, p. 46 e.v.

11. Art. 9 lid 1 Rome I Verordening luidt: '1. Bepalingen van bijzonder dwingend recht zijn bepalingen aan de inachtneming waarvan een land rechter deze conform artikel 9 lid 2 Rome I Verordening als lex fori dienen toe te passen ingeval de franchisegever in het buitenland is gevestigd, de franchisenemer in Nederland en de franchiseovereenkomst wordt beheerst door niet-Nederlands recht? ${ }^{12}$ Zal de Nederlandse rechter de buitenlandse rechtskeuze opzijzetten en de Nederlandse Wet franchise toepassen? Misschien nog interessanter is de vraag of - wanneer de franchiseovereenkomst niet alleen voorziet in een rechtskeuze voor niet-Nederlands recht, maar ook in een forumkeuze voor de niet-Nederlandse rechter - buitenlandse rechters de Wet franchise moeten gaan toepassen als voorrangsregel van een derde land in overeenstemming met artikel 9 lid 3 Rome I Verordening. ${ }^{13}$

\subsection{Voorrangsregel ex artikel 9 lid 1 Rome I Verordening}

Is artikel 7:922 BW een bepaling aan de inachtneming waarvan Nederland zoveel belang hecht voor de handhaving van zijn openbare belangen, zoals zijn politieke, sociale of economische organisatie, dat zij moet worden toegepast op elk geval dat onder de werkingssfeer ervan valt, ongeacht welk recht overeenkomstig de Rome I Verordening van toepassing is op de overeenkomst? Dat een voorrangsregel hieraan moet voldoen, vloeit namelijk voort uit de tekst van artikel 9 lid 1 Rome I Verordening. ${ }^{14}$

Voorop gesteld moet worden dat de kwalificatie 'voorrangsregels' of 'bepalingen van bijzonder dwingend recht' terughoudend moet worden toegepast. Dit volgt allereerst uit rechtspraak van het Hof van Justitie van de Europese Unie (HvJ EU). Dit oordeelde in dit verband - weliswaar met betrekking tot artikel $7 \mathrm{EVO}^{15},{ }^{16}$ - dat

zoveel belang hecht voor de handhaving van zijn openbare belangen zoals zijn politieke, sociale of economische organisatie, dat zij moet worden toegepast op elk geval dat onder de werkingssfeer ervan valt, ongeacht welk recht overeenkomstig deze verordening overigens van toepassing is op de overeenkomst.'

12. Artikel 9 lid 2 Rome I Verordening luidt: 2 . Niets in deze verordening beperkt de toepassing van de bepalingen van bijzonder dwingend recht van de rechter bij wie de zaak aanhangig is.

13. Artikel 9 lid 3 Rome I Verordening luidt: '3. De rechter kan ook gevolg toekennen aan de bepalingen van bijzonder dwingend recht van het land waar de verbintenissen krachtens de overeenkomst moeten worden nagekomen of zijn nagekomen, voor zover die bepalingen van bijzonder dwingend recht de tenuitvoerlegging van de overeenkomst onwettig maken. Bij de beslissing of aan deze bepalingen gevolg moet worden toegekend, wordt rekening gehouden met hun aard en doel alsmede met de gevolgen die de toepassing of niet-toepassing van deze bepalingen zou kunnen hebben.'

14. Vgl. HvJ EG 23 november 1999, C-369/96 en C-376/96, NJ 2000/251 (Arblade).

15. Europees Verdrag inzake het recht dat van toepassing is op verbintenissen uit overeenkomst, Rome 19 juni 1980, Trb. 1980, 156.

16. Het HvJ EU verwees uitdrukkelijk ook naar art. 9 Rome I Verordening, waarmee dit arrest ook voor dat artikel van belang is; HvJ EU 17 oktober 2013, ECLI:NL:XX:2013:243 (Unamar/Navigation Maritime), r.o. 48. Volledigheidshalve, art. 9 Rome I Verordening verschilt op twee punten van het EVO: (1) art. lid 1 Rome I Verordening bevat - in tegenstelling tot het EVO - een definitie van voorrangsregels, en (2) ingevolge art. 9 lid 3 Rome I Verordening komen niet alle buitenlandse voorrangsregel voor toepassing in aanmerking, maar alleen die waar de overeenkomst is of moet worden nagekomen; Asser/Kramer \& Verhagen 10-III 2015/931. Het arrest is daarmee ook nog relevant voor art. 9 Rome I Verordening. 
het beginsel van wilsautonomie van contractspartijen de hoeksteen vormt van het EVO. De uitzondering die bepalingen van bijzonder dwingend recht daarop kunnen maken, moet daarom strikt worden uitgelegd. ${ }^{17}$ Bij de beoordeling ${ }^{18}$ of bepalingen kwalificeren als bepalingen van bijzonder dwingend recht moet de nationale rechter ' $(. .$.$) niet alleen rekening houden met de precie-$ ze bewoordingen van deze bepalingen, maar ook met de algemene opzet en alle omstandigheden waarin deze bepalingen zijn vastgesteld, om daaruit te kunnen afleiden dat zij bepalingen van dwingend recht zijn, voor zover blijkt dat de nationale wetgever deze bepalingen heeft vastgesteld om een belang te beschermen dat voor de betrokken lidstaat fundamenteel is' ${ }^{19}$

Met andere woorden, er moet niet lichtvaardig worden aangenomen dat een bepaling als voorrangsregel heeft te gelden.

In dit verband, bij de vraag of een bepaling als een voorrangsregel moet worden gekwalificeerd, moet worden vastgesteld of deze bepaling voorrang claimt op het op de overeenkomst toepasselijke recht. Dit is een nationale toets. Hierbij is het doel van de wetgever die de relevante wettelijke bepaling heeft vastgesteld maatgevend. ${ }^{20}$

In de literatuur wordt verdedigd dat een dwingende bepaling pas als voorrangsregel kan worden aangemerkt indien het doel daarvan het dienen van een openbaar belang is. Dit 'dienen van een openbaar belang' moet op zodanige wijze geschieden dat doorkruising van het toepasselijk recht gerechtvaardigd is. ${ }^{21}$ In dit verband wijzen wij erop dat de Hoge Raad ten aanzien van de vraag of artikel 6 Buitengewoon Besluit Arbeidsverhoudingen 1945 (BBA) van toepassing was bij een door niet-Nederlands recht beheerste arbeidsovereenkomst, oordeelde dat dit afhing van de mate van betrokkenheid van de sociaaleconomische verhoudingen in Nederland (en in het bijzonder de belangen van de Nederlandse arbeidsmarkt bij de arbeidsovereenkomst en het ontslag). ${ }^{22} \mathrm{De}$ bescherming van 'structureel zwakkere partijen' is op zichzelf nog geen belang dat voldoende is om een beschermingsbepaling als een voorrangsregel te kwalifi-

17. HvJ EU 17 oktober 2013, ECLI:NL:XX:2013:243 (Unamar/Navigation Maritime), r.o. 49

18. Vgl. ook overweging 37 van de considerans van Rome I Verordening: 'Overwegingen van algemeen belang rechtvaardigen dat de rechters van de lidstaten zich in uitzonderlijke omstandigheden kunnen beroepen op rechtsfiguren zoals de exceptie van openbare orde en op bepalingen van bijzonder dwingend recht. Het begrip "bepalingen van bijzonder dwingend recht" moet worden onderscheiden van de uitdrukking "bepalingen waarvan niet bij overeenkomst kan worden afgeweken", en dient met meer terughouding te worden gebezigd.'

19. HvJ EU 17 oktober 2013, ECLI:NL:XX:2013:243 (Unamar/Navigation Maritime), r.o. 50, en zie ook Tekst \& Commentaar Burgerlijk Wetboek, Voorrangsregels bij: Burgerlijk Wetboek Boek 10, artikel 7 [Bijzonder dwingend recht], waar wordt gewezen op het gevaar van uitholling van het klassieke, meerzijdige verwijzingssysteem en onaanvaardbare verstoring van het internationale rechtsverkeer.

20. Asser/Kramer \& Verhagen 10-III 2015/935

21. Asser/Kramer \& Verhagen 10-III 2015/933.

22. HR 23 oktober 1987, ECLI:NL:PHR:1987:AD0017, NJ 1988/842. ceren, aldus ons hoogste rechtscollege. ${ }^{23}$ Wel heeft de Hoge Raad - wederom met betrekking tot het BBA beslist dat het private belang van de individuele werknemer meer voorop wordt gesteld in dit verband, dus bescherming van de werknemer alsmede bescherming van de Nederlandse arbeidsmarkt als openbaar belang. ${ }^{24}$ Dat zou dan weer afdoen aan de stelling dat bescherming van 'structureel zwakkere partijen' op zichzelf nog geen belang is dat voldoende is om een beschermingsbepaling als een voorrangsregel te kwalificeren. Het gaat - zoals wij dat zien - om een combinatie van samenhangende factoren en omstandigheden die een dergelijke zware kwalificatie dienen te legitimeren en dan met name de door de wetgever beoogde scope van de regeling die van fundamenteel belang moet zijn. ${ }^{25}$

\subsection{Oorspronkelijke tekst voorrangsregel?}

De memorie van toelichting op het (oorspronkelijke) wetsvoorstel noemt versterking van de positie van de franchisenemer in de pre-competitieve fase als reden voor het wetsvoorstel. ${ }^{26}$ Meer in het algemeen dient het ter bescherming van franchisenemers als de zwakkere partij binnen de franchiserelatie. ${ }^{27} \mathrm{Nu}$ franchiserelaties ook kwalificeren als diensten onder de Dienstenrichtlijn $^{28}$ - die ook communautaire dwingende voorschriften kent - is in het kader daarvan in de parlementaire behandeling van het hiervoor bedoelde (oorspronkelijke) wetsvoorstel opgemerkt dat de eisen die voortvloeien uit de franchisewet ' (...) zijn gerechtvaardigd om dwingende redenen van algemeen belang, in het bijzonder de redenen van openbare orde zoals opgesomd in artikel 16, eerste en derde lid, en zoals nader toegelicht in overweging 41 van de dienstenrichtlijn'. ${ }^{29}$ En even verderop

23. Asser/Kramer \& Verhagen 10-III 2015/934.

24. HR 24 februari 2012, ECLI:NL:HR:2012:BU8512, NJ 2012/274 (NUON/Olbrych). Zie ook Asser/Kramer \& Verhagen 10-III 2015/934.

25. Zie over de mate waarin 'regels van bijzonder dwingend recht' kunnen fungeren als bescherming van 'zwakkere' partijen: Van Bochove, Laura M., Overriding Mandatory Rules as a Vehicle for Weaker Party Protection in European Private International Law (November 30, 2014), Erasmus Law Review 2014/ 3.

26. Kamerstukken II 2019/20, 35392, nr. 3, p. 2.

27. Zie o.a. Kamerstukken II 2019/20, 35392, nr. 3, p. 13, 14 en 22.

28. Richtlijn 2006/123 van het Europees Parlement en de Raad van 12 december 2006 betreffende diensten op de interne markt (PbEU 2006, L 376).

29. Art. 16 lid 1 Dienstenrichtlijn luidt: '1. De lidstaten eerbiedigen het recht van dienstverrichters om diensten te verrichten in een andere lidstaat dan die waar zij gevestigd zijn. De lidstaat waar de dienst wordt verricht, zorgt voor vrije toegang tot en vrije uitoefening van een dienstenactiviteit op zijn grondgebied. De lidstaten maken de toegang tot en de uitoefening van een dienstenactiviteit op hun grondgebied niet afhankelijk van de naleving van eisen die niet aan de volgende beginselen voldoen:

a. discriminatieverbod: de eisen maken geen direct of indirect onderscheid naar nationaliteit of, voor rechtspersonen, naar de lidstaat waar zij gevestigd zijn;

b. noodzakelijkheid: de eisen zijn gerechtvaardigd om redenen van openbare orde, openbare veiligheid, de volksgezondheid of de bescherming van het milieu;

c. evenredigheid: de eisen moeten geschikt zijn om het nagestreefde doel te bereiken en gaan niet verder dan wat nodig is om dat doel te bereiken.'

Art. 16 lid 3 Dienstenrichtlijn luidt: '3. De lidstaat waarnaar de dienstverrichter zich begeeft, wordt niet verhinderd om, in overeenstemming met lid 1, eisen aan het verrichten van een dienstenactiviteit te stellen 
wordt gerefereerd aan 'het fundamentele belang van bescherming van de afhankelijke en daarmee zwakkere partij in de franchiserelatie'. ${ }^{30}$

Dit lijkt allemaal te wijzen in de richting van de bedoeling om de bepalingen aan te merken als voorrangsregel. Echter, gezien de vereisten en bewoordingen van artikel 16 Dienstenrichtlijn is de vraag of dit wel zo bedoeld was. Artikel 16 lid 1 Dienstenrichtlijn eist bijvoorbeeld dat - kort gezegd - nieuwe wetgeving in een lidstaat onder meer noodzakelijk is. Dat wil zeggen: dergelijke wetgeving is gerechtvaardigd om redenen van openbare orde, openbare veiligheid, de volksgezondheid of de bescherming van het milieu. ${ }^{31}$ De toelichting van de wetgever bij het oorspronkelijke artikel 7:922 BW lijkt eerder toegespitst te zijn op de Dienstenrichtlijn dan op de kwalificatie als voorrangsregel. Wie het echter weet, mag het zeggen.

Een andere interpretatie zou er namelijk toe kunnen leiden dat bij elke nieuwe wet die in zijn motivering verwijst naar deze vereisten van de Dienstenrichtlijn, de discussie ontstaat of deze bedoeld is als voorrangsregel. Bovendien valt deze toelichting lastig te rijmen met de - eerdergenoemde - opmerkingen over rechtskeuzes in de memorie van toelichting en de nota naar aanleiding van het verslag. ${ }^{32}, 33$ Namelijk dat het aan partijen is om te bepalen welk recht van toepassing is op de franchiseovereenkomsten, ongeacht waar ter wereld de franchiseketen actief is, en dat - onder verwijzing naar artikel 3 lid 3 Rome I Verordening - waar zowel de franchisenemer als de franchisegever een Nederlandse partij is en de franchiseovereenkomst uitsluitend met Nederland verbonden is, artikel 7:922 $\mathrm{BW}$ meebrengt dat partijen

als deze gerechtvaardigd zijn om redenen in verband met de openbare orde, de openbare veiligheid, de volksgezondheid of de bescherming van het milieu. Ook wordt die lidstaat niet verhinderd om in overeenstemming met het Gemeenschapsrecht zijn voorschriften inzake de arbeidsvoorwaarden toe te passen, waaronder die welke zijn neergelegd in collectieve arbeidsovereenkomsten.'

30. Kamerstukken II 2019/20, 35392, nr. 3, p. 13

31. Art. 16 lid 1 onder b en lid 3 Dienstenrichtlijn.

32. Kamerstukken II 2019/20, 35392, nr. 3, p. 50: 'Als zowel de franchisenemer als de franchisegever Nederlandse partijen zijn en de franchiseovereenkomst uitsluitend met Nederland verbonden is, brengt artikel 7:922 eveneens mee dat zij niet door middel van een rechtskeuze van de dwingendrechtelijke bepalingen in deze titel kunnen afwijken (vgl. artikel 3, derde lid, Verordening Rome I).'

33. Kamerstukken II 2019/20, 35392, nr. 6, p. 26 en 27: 'Een verplichting voor in Nederland gevestigde franchisegevers om Nederlands recht toe te passen tegenover niet in Nederland gevestigde franchisenemers, is er niet. Het staat ondernemingen (los van waar ze zijn gevestigd) bij een overeenkomst in principe vrij om zelf het op de overeenkomst toepasselijke recht te bepalen door middel van een rechtskeuze. Het is derhalve aan partijen om te bepalen welk recht van toepassing is op de franchiseovereenkomsten, ongeacht waar ter wereld de franchiseketen actief is. (...) Voor de goede orde wordt nog opgemerkt dat een Nederlandse franchisegever in beginsel ook gerechtigd is om in franchiseovereenkomsten met Nederlandse franchisenemers te kiezen voor buitenlands recht. Echter, ingevolge artikel 3, derde lid, van Rome I, geldt dat indien op het moment van die rechtskeuze alle aanknopingspunten van de verbintenis zich bevinden in Nederland, ondanks de rechtskeuze voor buitenlands recht de dwingendrechtelijke Nederlandse bepalingen in acht moeten worden genomen (waaronder dus de franchisebepalingen uit dit wetsvoorstel). De rechtskeuze laat dwingendrechtelijke bepalingen van dat land waar alle aanknopingspunten van die verbintenis zich bevinden, onverlet.' niet door middel van een rechtskeuze van de dwingendrechtelijke bepalingen in titel 16 kunnen afwijken. Dit impliceert dat indien beide partijen niet-Nederlands zijn, of - indien dat wel het geval is - de franchiseovereenkomst niet exclusief met Nederland is verbonden, partijen wél kunnen afwijken van de franchisewet. Daaruit zou de conclusie getrokken kunnen worden dat de wetgever het karakter van de bepalingen blijkbaar aanmerkt als 'bepalingen waarvan niet bij overeenkomst kan worden afgeweken'. Was dat niet het geval geweest, dan waren deze opmerkingen niet op zijn plaats geweest, of had de wetgever op zijn minst kunnen verwijzen naar de voorrangsregels in artikel 9 Rome I Verordening. Simpel gezegd vanuit ipr-perspectief: het ene dwingende recht (art. 3 Rome I Verordening) is zeker het andere niet (art. 9 Rome I Verordening).

\subsection{Voorrangsregel na amendement?}

De vraag is dan of het amendement van de Kamerleden Palland en Aartsen (en de toelichting daarop) de mogelijke kwalificatie beïnvloedt van de definitieve tekst van artikel 7:922 $\mathrm{BW}$ als 'bepalingen van bijzonder dwingend recht'. Het gaat dan om de toevoegingen 'ten aanzien van in Nederland gevestigde franchisenemers (...)' en '(..) ongeacht het recht dat de franchiseovereenkomst beheerst'. Dit lijkt te duiden op een exclusief protectionistisch karakter, zoals hiervoor ook is opgemerkt. Als dit bij een internationale overeenkomst zomaar kan worden weggecontracteerd door middel van een rechtskeuze voor een buitenlands recht, dan is de tijger behoorlijk tandeloos dunkt ons.

De indieners merken op dat dit amendement regelt dat niet ten nadele van in Nederland opererende franchisenemers van de Wet franchise mag worden afgeweken. Wel kan ten nadele van buiten Nederland opererende franchisenemers worden afgeweken, zelfs als een rechtskeuze voor Nederlands recht is gemaakt. Verder beoogt het amendement - als gezegd - franchisenemers die in Nederland actief zijn te beschermen in situaties waarbij het overwicht van de franchisegever tot onredelijke en onwenselijke situaties kan leiden voor de franchisenemer. Daarnaast heeft het amendement tot doel maatwerk te bieden voor franchisegevers en franchisenemers in Nederland. ${ }^{34}$ Onduidelijk is of de indieners hiermee het oog hebben gehad op voorrangsregels.

De behandeling in de Tweede Kamer biedt in dit verband weinig aanknopingspunten. Op de vraag waarom Kamerlid Aartsen het amendement heeft ingediend antwoordt hij:

'(...) Misschien is het goed om te vermelden dat dit amendement ervoor zorgt dat de regels en het doel van deze wet met name voor het Nederlandse grondgebied gelden. Ik denk dat dat heel logisch is, omdat dit de problemen hier in Nederland aanpakt. Alleen, het kabinet kiest voor dwingend recht. Ook dat snap $\mathrm{ik}$, want ik schetste net het probleem van de contractvrijheid. Als je dat niet zou doen, dan is het eenvou- 
dig om als penvoerder van zo'n contract te zeggen: nou, dan wijken we af van de wet en als u niet tekent, sorry, dan heeft u geen onderneming. Ik denk dus dat het verstandig is om deze wet onder dwingend recht te laten vallen. Voor partijen die in Nederland gevestigd zijn wegens het vestigingsklimaat, waarvoor veel werkgelegenheid in Nederland is en waar veel mensen en veel gezinnen werken, is het probleem natuurlijk wel dat als je dwingend recht gaat toepassen, je dat ook moet doen voor al die situaties in de rest van de wereld. Volgens mij schaadt dat onze internationale concurrentiepositie. Dat schaadt een hele hoop Nederlandse bedrijven. Dat schaadt een hele hoop internationale bedrijven die een gezonde boterham verdienen, ook met franchiseformules buiten Nederland. Daarom denk ik dat het verstandig is om te zeggen: dit is de leidende wet, maar het staat $\mathrm{u}$ vrij om daarvan af te wijken als u dat beiden overeenkomt. ${ }^{35}$

Op vervolgvragen in dit verband antwoordt hij verder:

'(...) Mijn vrees is namelijk dat het schadelijk is als deze wet ook zou moeten gelden voor een internationale formule die in Nederland gevestigd is, die hier veel banen biedt, waar veel gezinnen een gezonde boterham van kunnen eten, en als die daarmee beperkt wordt om zaken te doen met een miljoenenof miljardenbedrijf in Zuid-Amerika. Dat gaat uiteindelijk banen kosten voor Nederland. Dat willen we voorkomen met het amendement. Daarom lijkt het mij verstandig om dat nu te bezien en dat op deze manier uit de wet te halen. Als uit de evaluatie blijkt dat het een en al kommer en kwel is omdat er allerlei schijnconstructies zijn gebruikt ... Maar dat verwachten wij niet. Iedereen die zich op Nederlands grondgebied begeeft, dient zich aan deze wet te houden. Omdat het kabinet kiest voor dwingend recht lijkt het mij onverstandig om dit ook voor internationale partijen te laten gelden. Dat kost Nederland uiteindelijk gewoon banen. Dat moeten we zeker in deze tijd niet willen. ${ }^{36}$

Zijn collega Palland meldt (deels over het oorspronkelijke wetsvoorstel en deels over het amendement):

'[...] Verder hebben wij vragen bij de extraterritoriale werking van het wetsvoorstel, ook in het verslag opgenomen. Er is immers een behoorlijk aantal internationaal opererende franchisegevers. Het is goed en logisch dat dit wetsvoorstel van toepassing is op alle franchisegevers en franchisenemers, actief en gevestigd hier in Nederland, ook als de franchisegever in het buitenland is gevestigd. Daarmee wordt ook een vlucht naar het buitenland onaantrekkelijk gemaakt of voorkomen. In de beantwoording op onze vragen hierover is aangegeven dat er geen inschatting te maken is van de effecten van deze extraterritoriale werking en is de staatssecretaris ingegaan op de uitvoerbaarheid bij master franchise setups in internationale context. Maar er is niet altijd sprake van een master franchise setup. Het blijft ons niet duidelijk waarom deze extraterritoriale werking via dwingend recht nodig zou zijn. Wij kunnen ons voorstellen dat we ter voorkoming van conflicterende rechtsregels in andere landen en het werkbaar houden van de regels ruimte laten aan franchisegevers en in het buitenland gevestigde franchisenemers om afspraken te maken, ook om ons vestigingsklimaat aantrekkelijk te houden. Daarom hebben wij een amendement op dit punt ingediend. ${ }^{37}$

De kern van het verhaal van Kamerleden Palland en Aartsen lijkt te zijn dat de wet op Nederlands grondgebied dwingend dient te zijn, maar dat dit niet zou moeten gelden voor internationale partijen. Wij krijgen onze vinger er niet achter of zij bedoeld hebben de regel altijd toepasselijk te willen laten zijn in het geval de franchisenemer in Nederland is gevestigd. Zij verwijzen verder niet naar een (te beschermen) openbaar belang of sociaaleconomische verhoudingen. Maar de vraag dringt zich wel op of de wettekst in zichzelf daarvoor niet al aanwijzend is. De verklaringen van de leden Palland en Aartsen werpen niet een nieuw of ander licht op de kwalificatievraag. Wel wijzen de toevoegingen in de richting van voorrangsregels, en dan in het bijzonder '(...) ongeacht het recht dat de franchiseovereenkomst beheerst'. Het is jammer om te concluderen: wij kunnen er geen chocola van maken.

\subsection{Conclusie?}

In het licht van het vorenstaande is lastig vast te stellen of de oorspronkelijke en de definitieve tekst van artikel 7:922 BW als voorrangsregel zou moeten worden aangemerkt. Aan de ene kant dient de wet ter bescherming van franchisenemers als de zwakkere partij binnen de franchiserelatie. Bovendien noemt de memorie van toelichting - weliswaar in het kader van de Dienstenrichtlijn - dat de wet is gerechtvaardigd om dwingende redenen van algemeen belang, in het bijzonder de redenen van openbare orde. Daarnaast bepaalt de (definitieve) wettekst dat de regelgeving dwingend is, ongeacht het recht dat de overeenkomst beheerst. Aan de andere kant moet kwalificatie als voorrangsregel zeker niet te lichtvaardig worden aangenomen. Sterker nog, het door de Europese rechter gewezen Arblade-arrest dat aan artikel 9 lid 1 Rome I Verordening ten grondslag ligt, stelt hoge eisen. Ook kan hier genoemd worden dat op andere plekken in de parlementaire documentatie met betrekking tot de oorspronkelijke tekst wordt gesuggereerd dat een rechtskeuze voor niet-Nederlands recht de franchisewet wel 'opzij kan zetten'. Om een lang verhaal kort te maken, het huidige artikel 7:922 BW vertoont de contouren van een voorrangsregel in de zin van artikel 9 lid 1 Rome I Verordening, maar of dit ook daadwerkelijk als een voorrangsregel is aan te merken, valt te bezien. 
De rechter zal dan veel 'strekking' in de wettekst moeten (willen) lezen.

Een alternatieve zienswijze is om artikel 7:922 BW te 'splitsen'. Artikel 7:922 BW bepaalt dat niet ten nadele van franchisenemers kan worden afgeweken van titel 16 , en dat een beding in strijd met artikel 7:920 BW nietig is, ongeacht het recht dat de franchiseovereenkomst beheerst. Met andere woorden, de sanctie op schending van artikelen 7:911 tot en met 7:919 BW en artikel 7:921 $\mathrm{BW}$ is - ex artikel 3:40 lid $2 \mathrm{BW}$ - vernietigbaarheid, ${ }^{38}$ terwijl strijd met artikel 7:920 BW nietigheid oplevert. ${ }^{39}$ Gezien het belang dat de wetgever aan artikel 7:920 BW hecht - bedingen in strijd met dit artikel acht de wetgever zonder meer onwenselijk ${ }^{40}$ - kan dat wellicht eerder worden gezien als een bepaling ter bescherming van een openbaar belang als bedoeld in artikel 9 lid 1 Rome I Verordening. De overige bepalingen van titel 16 zien voornamelijk slechts op de bescherming van één partij en zijn daarom wellicht te 'zwak' om aangemerkt te worden als een voorrangsregel.

\section{Lex fori artikel 9 lid 2 Rome I Verordening}

Mocht artikel 7:922 BW (geheel of gedeeltelijk) als voorrangsregel worden gekwalificeerd, dan rijst de vraag of de aangezochte Nederlandse rechter deze ex artikel 9 lid 2 Rome I Verordening als lex fori moeten toepassen indien de franchisegever in het buitenland is gevestigd, de franchisenemer in Nederland en de franchiseovereenkomst wordt beheerst door niet-Nederlands recht. Zal de Nederlandse rechter de buitenlandse rechtskeuze opzijzetten en de Nederlandse Wet franchise toepassen?

De Nederlandse rechter is in beginsel terughoudend met het kwalificeren van Nederlandse bepalingen als voorrangsregels. ${ }^{41}$ Maar wanneer de Nederlandse rechter die horde neemt, moet de Nederlandse rechter vervolgens oordelen of deze in een concreet geval moet worden toegepast. Dat moet plaatshebben op basis van het nationale rechtsstelsel waar de voorrangsregel deel van uitmaakt. Er zal in dat geval gekeken moeten worden of dit rechtsstelsel een scope rule heeft voor de van een der partijen bij een meerzijdige rechtshandeling, art. 3:40 lid 2 BW.

39. Kamerstukken II 2019/20, 35392, nr. 3, p. 49. Hierbij tekent de wetgever overigens aan dat art. 3:40 BW rechtshandelingen als aangrijpingspunt hanteert. Is er geen sprake van een rechtshandeling in strijd met een dwingende rechtsbepaling (bijv. het verbod om de franchisenemer aan te zetten tot investeringen tijdens de standstillperiode van vier weken), dan zullen vorderingen op grond van onrechtmatige daad, dwaling of bedrog uitkomst kunnen bieden; Kamerstukken II 2019/20, 35392, nr. 3, p. 50

40. Kamerstukken II 2019/20, 35392, nr. 3, p. 49

41. Asser/Kramer \& Verhagen 10-III 2015/938; HR 23 oktober 1987 ECLI:NL:PHR:1987:AD0017, NJ 1988/842. voorrangsregel. ${ }^{42}$ Is dat het geval, en vloeit daaruit voort dat de voorrangsregel moet worden toegepast, dan moet worden vastgesteld wat de rechtsgevolgen van de toepasselijkheid van de voorrangsregel zijn. Indien de voorrangsregel zelf geen civielrechtelijke sancties bevat, zal de rechter moeten terugvallen op artikel 3:40 BW. Voorziet de voorrangsregel wel zelf in de effecten, dan kan de rechter daarop terugvallen. ${ }^{43}$

Indien ervan uit wordt gegaan dat artikel 7:922 BW als voorrangsregel kwalificeert, zal de Nederlandse rechter moeten vaststellen of deze in een concreet geval inderdaad moet worden toegepast. Artikel 7:922 BW bevat zelf een scope rule; het artikel is van toepassing op in Nederland gevestigde franchisenemers, ongeacht het recht dat de franchiseovereenkomst beheerst. Dus als de rechter heeft kunnen vaststellen dat er sprake is van een franchiseovereenkomst en de franchisenemer in Nederland is gevestigd, dan zal de rechter artikel 7:922 BW in beginsel moeten toepassen. Daar waar de franchiseovereenkomst in strijd is met artikel 7:920 BW - dat wil zeggen met de goodwillregeling of de non-concurrentieregels - zal de Nederlandse rechter de relevante bepalingen van de franchiseovereenkomst ambtshalve nietig moeten verklaren. Waar de franchiseovereenkomst voor het overige in strijd is met titel $16 \mathrm{zal}$ de franchisenemer de vernietigbaarheid daarvan moeten inroepen.

\section{Artikel 9 lid 3 Rome I Verordening}

Wellicht de meest interessante kwestie met betrekking tot artikel 7:922 $\mathrm{BW}$ is de vraag hoe een buitenlandse rechter met de bepaling om zal gaan. De vraag of - wanneer de franchiseovereenkomst niet alleen voorziet in een rechtskeuze voor niet-Nederlands recht, maar ook een forumkeuze voor de niet-Nederlandse rechter - buitenlandse rechters de Wet franchise moeten gaan toepassen als voorrangsregel van een derde land en of dat in overeenstemming is met artikel 9 lid 3 Rome I Verordening.

De reikwijdte van artikel 9 lid 3 Rome I Verordening is beperkt. ${ }^{44}$ Allereerst moet het voorrangsregels betreffen van het land waar de verbintenissen zijn of moeten worden nagekomen. Verder moet het gaan om voorrangsregels die de tenuitvoerlegging van de overeenkomst onwettig maken. ${ }^{45}$ In de literatuur wordt

42. Asser/Kramer \& Verhagen 10-III 2015/939

43. Asser/Kramer \& Verhagen 10-III 2015/940

44. Er lijkt door opname van art. 9 lid 3 Rome I Verordening een verenging te zijn nagestreefd in vergelijking met het voorheen geldende art. 7 lid 1 EVO; zie Van Wechem 2008, p. 49

45. Zie ook Tekst \& Commentaar Vermogensrecht, Uitleg bij: Verordening (EG) nr. 593/2008 inzake het recht dat van toepassing is op verbintenissen uit overeenkomst, Artikel 9 Bepalingen van bijzonder dwingend recht, die meldt dat hierbij moet worden gedacht aan (semi)publiekrechtelijke regels die nakoming juridisch eigenlijk onmogelijk maken, zoals exportverboden. 
betoogd dat dit betekent dat de overeengekomen prestaties of de inhoud van de overeenkomst in strijd moeten zijn met de wet. Voorrangsregels die niet zien op het verbieden van prestaties, vallen niet onder artikel 9 lid 3 Rome I Verordening. Dus wettelijke bepalingen die de opzegging van overeenkomsten beperken of die in geval van beëindiging van een overeenkomst een vergoeding toekennen aan een partij zouden niet worden bestreken door artikel 9 lid 3 Rome I Verordening. ${ }^{46}$ Ten slotte moet bij de beoordeling of aan deze voorrangsregels effect moet worden toegekend, rekening worden gehouden met (1) hun aard en doel, en (2) de gevolgen die de toepassing of niet-toepassing van deze voorrangsregels zou kunnen hebben.

De vraag is nu hoe dit uitwerkt in het hiervoor genoemde voorbeeld, dat wil zeggen een franchiseovereenkomst die wordt beheerst door buitenlands recht, maar is gesloten met een franchisenemer die actief is in Nederland en een franchisegever die gevestigd is buiten Nederland. Zijn de regels van titel 16 voorrangsregels die de tenuitvoerlegging van de overeenkomst onwettig maken? Die drempel lijkt lastig te nemen. Afwijken ten nadele van de franchisenemer van artikel 7:922 BW resulteert in nietigheid, afwijkingen van de overige bepalingen in vernietigbaarheid. Maken eventuele afwijkingen ten nadele van de franchisenemer de uitvoering daarmee onwettig? Bovendien, zou worden aangesloten bij de positie dat het moet gaan om voorrangsregels die prestaties verbieden, dan zou een van de belangrijkste aspecten van de franchisewet, namelijk de goodwillregeling in artikel 7:920 BW, niet voor toepassing in aanmerking komen. Deze bevat regels over de aanwezigheid, omvang, toerekening en uitbetaling van goodwill aan de franchisenemer bij het einde van de overeenkomst, maar verbiedt geen prestaties. Of is de algemene bepaling van artikel 7:922 $\mathrm{BW}$ - afwijken ten nadele van de franchisenemer is niet toegestaan - aan te merken als een verbod op prestaties?

Een evenzo belangrijke beperking wordt gevormd door het vereiste om rekening te houden met de aard en het doel van de franchisewet, en de gevolgen van toepassing of niet-toepassing. Over dit laatste oordeelde de Hoge Raad recentelijk - over de toepassing van een buitenlandse voorrangsregel - kort gezegd dat (1) bij de beslissing of aan derde-landvoorrangsregels gevolg moet worden toegekend, rekening moet gehouden met hun aard en doel en met de gevolgen die de toepassing of niet-toepassing van deze bepalingen zou kunnen hebben; (2) de toepassing van een dwingende bepaling van een ander land gerechtvaardigd moet zijn door haar aard en strekking; en (3) artikel 7 lid 1 EVO (grotendeels gelijk aan art. 9 lid 3 Rome I Verordening) volgens de rechtspraak van het HvJ EU strikt moet worden uitgelegd. ${ }^{47}$ Met andere woorden, zelfs als een regel als voorrangsregel kwalificeert, betekent dat niet automatisch

46. Asser/Kramer \& Verhagen 10-III 2015/942.

47. HR 18 september 2020, ECLI:NL:HR:2020:1443, r.o. 3.3.2. dat deze door een rechter als derde-landvoorrangsregel moet worden toegepast.

Een voorbeeld van buitenlands recht dat als bijzonder dwingend recht wordt beschouwd onder artikel 9 lid 1 Rome I Verordening is de Belgische alleenverkoopwet. ${ }^{48}$ Het karakter van bijzonder dwingend recht volgt uit de samenlezing van artikelen 4 en 6 van die wet. Artikel 4 luidde als volgt: 'De benadeelde concessiehouder kan, bij de beëindiging van een verkoopconcessie met uitwerking voor het gehele Belgische grondgebied of een deel ervan, in elk geval de concessiegever in België dagvaarden, hetzij voor de rechter van zijn eigen woonplaats, hetzij voor de rechter van de woonplaats of de zetel van de concessiegever. Ingeval het geschil voor een Belgische rechtbank wordt gebracht, zal deze uitsluitend de Belgische wet toepassen.' Artikel 6 bepaalde vervolgens: 'De bepalingen van deze wet zijn van toepassing niettegenstaande hiermede strijdige overeenkomsten, gesloten vóór het einde van het contract waarbij de concessie is verleend.' Artikel 6 resulteerde er aldus in dat de regel van artikel 4 dwingend van karakter was in de zin van artikel 9 lid 1 Rome I Verordening. Inmiddels is het voorgaande overgezet in artikel 39 van boek $\mathrm{X}$ in het Belgisch Wetboek Economisch Recht. ${ }^{49}$ Een Belgische rechter zal aldus op basis van artikel 9 lid 2 Rome I Verordening de regels van de alleenverkoopwet toepassen, ook ingeval de distributieovereenkomst wordt beheerst door niet-Belgisch recht. Echter, voor toepassing daarvan door een buitenlandse rechter ingevolge artikel 9 lid 3 Rome I Verordening lijkt in beginsel geen plaats te zijn. Strijd met de Belgische regels inzake alleenverkoop maakt de tenuitvoerlegging van de overeenkomst in beginsel niet onwettig. Er dient enkel een opzegtermijn in acht te worden genomen en bijkomende schadevergoeding te worden gegeven. ${ }^{50}$

Al met al kan uiteraard niet worden uitgesloten dat een buitenlandse rechter ingevolge artikel 9 lid 3 Rome I Verordening de Nederlandse franchisewet gaat toepassen. Echter, een buitenlandse rechter moet daar wel de hobbels 'kwalificatie voorrangsregel', 'uitvoering onwettig' en 'aard, doel en gevolgen' voor nemen. ${ }^{51}$ In dat licht lijkt het er volgens ons op het eerste gezicht op dat de drempel van artikel 9 lid 3 Rome I Verordening te hoog is voor artikel 7:922 BW.

48. Wet van 1961, art. 4 en 6 .

49. In werking getreden per 1 mei 2014. De Belgische wetgever heeft vergeten om naast art. 4 ook art. 6 over te zetten. Echter, dit maakt geen verschil nu duidelijk is dat de bepalingen van art. 4 dwingend zijn.

50. Althans dit is hoe wij art. 4 en 6 van de Belgische alleenverkoopwet en art. 39 van Boek X van het Belgisch Wetboek Economisch Recht begrijpen en lezen.

51. Dit geldt enkel voor landen die gebonden zijn door de Rome I Verordening. Bij landen waarbij dat niet het geval is, moet op basis van het internationaal privaatrecht van de aangezochte rechter van geval tot geval worden bekeken of er ruimte is voor de toepassing van derdelands voorrangregels en zo ja of titel 16 daarvoor in aanmerking komt. 


\section{Conclusie}

Alles in ogenschouw nemend komt artikel 7:922 BW in ieder geval in de buurt van de kwalificatie als voorrangsregel in de zin van artikel 9 lid 1 Rome I Verordening. Maar of dit nu een 'volwaardige' voorrangsregel, is kan op voorhand niet met zekerheid gezegd worden. De toelichting op de wetsartikelen zijn - althans dat menen wij - te onduidelijk op dat punt.

Mocht het wel als een voorrangsregel aangemerkt worden, dan zien wij weinig obstakels - indien de franchiseovereenkomst tussen een buitenlandse franchisegever en een in Nederland gevestigde franchisenemer wordt beheerst door buitenlands recht, maar waar de Nederlandse rechter bevoegd is - dat deze ingevolge artikel 9 lid 2 Rome I Verordening door de angezochte rechter als voorrangsregel van het lex fori wordt toegepast. Echter, mits de Nederlandse rechter heeft vastgesteld dat deze in een concreet geval inderdaad moet worden toegepast. Als derde-landvoorrangsregel zien we daar minder ruimte voor. Het lijkt erop dat artikel 7:922 BW 'te licht' is om voor toepassing op grond van artikel 9 lid 3 Rome I Verordening in aanmerking te komen. Dat gezegd hebbend: wil een buitenlandse franchisegever de kans vergroten om buiten het bereik van titel 16 te blijven, dan doet hij er verstandig aan om niet alleen niet-Nederlandse recht van toepassing te verklaren, maar ook te kiezen voor een (exclusieve) forumkeuze buiten Nederland. ${ }^{52}$

122 Maar nu het antwoord op de vraag waar wij het artikel mee begonnen: is artikel 7:922 BW een voorrangsregel waar de praktijk op moet voorsorteren? Wij kunnen, zoals wij hiervoor hebben angegeven, deze vraag niet met zekerheid beantwoorden. Het lijkt ons wel verstandig om, met name aan buitenlandse franchisegevers die zakendoen met in Nederland gevestigde franchisenemers, wanneer buitenlands recht van toepassing is verklaard, hierover een bepaalde mate van bedachtzaamheid uit te spreken. Aan het eind van de dag: de tijd zal het uitwijzen. 